\title{
PENGARUH KECERDASAN MATEMATIS LOGIS MAHASISWA TERHADAP KEMAMPUAN PENALARAN DASAR MATEMATIKA DAN STATISTIKA FARMASI
}

\author{
Andi Soewandi $^{1 *}$,Ainaya Rachmaulidya ${ }^{2},{\text { Bagas Apriliano } W^{3} \text {, Muhammad Nur Prana }}^{4}$ \\ ${ }^{1}$ Program Studi Farmasi Institut Sains Teknologi Nasional \\ ${ }^{2}$ Program Studi Farmasi Institut Sains Teknologi Nasional \\ ${ }^{3}$ Program Studi Farmasi Institut Sains Teknologi Nasional \\ ${ }^{4}$ Program Studi Farmasi Institut Sains Teknologi Nasional
}

\begin{abstract}
ABSTRAK
Kemampuan bernalar sangat dibutuhkan bagi siswa maupun mahasiswa dalam memahami materi atau konsep matematika dan statistika. Penelitian ini merupakan penelitian penelitian asosiatif denganpendekatan kuantitatif. Dalam penelitian ini, peneliti membahas pengaruhkecerdasan matematislogis terhadap kemampuan penalaran yang data-datanya dihitung secara kuantitatif. Sampel penelitian seluruh mahasiswa farmasi semester 1 yang terdiri dari 42 mahasiswa. Metode pengumpulan data yang digunakan adalah tes, wawancara,observasi, dan dokumentasi. Teknik analisis data yang digunakanadalah analisis regresi linier sederhana. Hasil penelitian menunjukkan bahwa tingkat kecerdasan matematis logis mahasiswa farmasi semester 1 tahun Ajaran 2017/2018 sebagian besar berada padakategori sedang dengan presentase sebesar $66,67 \%$ sedangkan tingkat kemampuan penalaran dasar sebagian besar juga berada pada kategori sedang dengan persentase sebesar $73,81 \%$. disimpulkan bahwa kecerdasan matematis logis berpengaruh sebesar 19,67\% terhadap kemampuan penalaran dasar mahasiswa farmasi semester 1 Universitas Peradaban sedangkan sisanya 80,33\% dipengaruhi oleh faktor lain.
\end{abstract}

\section{Kata kunci : Kecerdasan Matematis Logis, Kemampuan Penalaran}

\section{PENDAHULUAN}

Kecerdasan merupakan salah satu faktor penting yang dapat mempengaruhi prestasi seseorang. Sehingga sukses dan gagalnya siswa ditentukan oleh kecerdasan yang dimilikinya. Biasanya siswa yang memiliki kecerdasan rendah sulit diharapkan dapat berprestasi tinggi. Akan tetapi tak jarang siswa yang memiliki kecerdasan rendah yang berprestasi, sehingga tidak ada jaminan jika kecerdasan tinggi seorang siswa secara otomatis akan sukses belajar di sekolah.

Howard Gardner (2004:95) menemukan kecerdasan majemuk (multiple intelegences), bahwa ada banyak kecerdasan yang dimiliki setiap orang. Kecerdasan tersebut diantaranya kecerdasan verbal linguistik, matematis logis, visual-spasial, kinestetik, musik, interpersonal, naturalis dan eksistensialis. Teori ini juga menekankan pentingnya pemodelan dalam mengembangkan salah satu kecerdasan yang dimiliki siswa. Materi mata kuliah Pengantar Dasar Statistika Farmasi pada kelas Farmasi merupakan materi yang bersifat abstrak, selain itu juga penuh dengan permasalahan yang harus dipecahkan. Salahsatu tujuan dari pembelajaran tersebut adalah mendorong mahasiswa dapat menyelesaikan masalah berdasarkan proses berpikir kritis, logis, dan rasional. Sehingga kemampuan mahasiswa dalam pemecahan masalah memiliki peran penting dalam mencapai tujuan pembelajaran. Kecerdasan matematis logis merujuk pada kemampuan dalam mengeksplorasi pola- pola, kategori dan hubungan dengan manipulasi objek atau simbol untuk melakukan percobaan dengan cara yang teratur dan terkontrol.
Mahasiswa dengan kecerdasan matematislogis tinggi sangat suka dengan bilangan, simbol-simbol dan menghitung, baik dalam penalaran maupun pemecahan masalah. Menurut NCTM (National Council of Teachers of Mathematics) menyebutkan bahwa standar proses dalam pembelajaran matematika adalah untuk mengembangkan kemampuan: (1) pemecahan masalah (problem solving), (2) penalaran (reasoning and proof), (3) koneksi (connection), (4) komunikasi (communication), (5) representasi (representation).

Kemampuan penalaran sangat berperan dalam meningkatkan kompetensi matematika, yakni dalam pemahaman konsep, pemecahan masalah serta meningkatkan kemampuan komunikasi. Mengingat salah satu tujuan pembelajaran matematika adalah untuk memecahkan, penalaran sangat dibutuhkan untuk mencari solusi yang tepat dalam pemecahan masalah yang berkaitan dengan statistika dasar. Dalam menyelesaikan permasalahan yang berkaitan dengan statistika dasar farmasi, setiap orang memiliki cara yang berbeda untuk menyelesaikannya sehingga sangat memungkinkan bagi mahasiswa untuk mencoba berbagai macam penalaran dalam proses menyelesaikan masalah tersebut. Berdasarkan pengalaman peneliti dalam mengajar mata kuliah pengantar dasar statistika mahasiswa masih kesulitan dan belum memahami simbol-simbol dalam memanipulasi rumus untuk menyelesaikan soal statistika farmasi, hal ini mengakibatkan kemampuan penalaran yang dimiliki mahasiswa rendah.

Rendahnya kemampuan penalaran mahasiswa terlihat pada kesanggupan mahasiswa untuk 
menyelesaikan masalah dengan melibatkan proses mengumpulkan fakta, mengelola, menganalisis, menjelaskan, dan membuat kesimpulan. Pada waktu perkuliahan mata kuliah matematika dan statistika mahasiswa belum terlalu paham dengan materi yang disampaikan. Oleh karena itu, butuh beberapa kali pertemuan dalam menjelaskan suatu materi agar siswa benar- benar paham. Selain itu, dosen juga perlu menerapkan model atau pendekatan pembelajaran yang cocok dengan karakteristik mahasiswa agar kemampuan penalaran mahasiswa bisa meningkat dalam pembelajaran matematika dan statistika. Salah satu faktor penyebabnya adalah mahasiswa farmasi semester 1 berasal dari SMK atau SMA yang bukan jurusan IPA atau farmasi sehingga kemampuan matematika dasar berbeda-beda, selain itu jumlah jam pelajaran matematika pada tingkat SMA/SMK sangat terbatas. Bertitik tolak pada uraian di atas, kecerdasan matematis logismemiliki kecenderungan mahasiswa yang pandai yang dapat memecahkanmasalah dan dapat menyimpulkan dari apa yang telah dikerjakan serta memahami hal-hal yang bersifat abstrak. Sebagian besar materi pada mata kuliah pada statistika dasar bersifat abstrak dan beberapa soal berupa soal penalaran dan penerapan sehingga kemampuan penalaran dasar matematis sangat diperlukan untuk menyelesaikan soal yang berkaitan dengan statistika dasar farmasi.

\section{METODE}

Penelitian ini merupakan penelitian penelitian asosiatif dengan pendekatan kuantitatif. Penelitian asosiatif adalah penelitian yang dimaksudkan untuk mengetahui hubungan dua variabel atau lebih. Sedangkan penelitian kuantitatif adalah metode yang digunakan untuk meneliti pada populasi atau sampel tertentu, teknikpengambilan sampel pada umumnya dilakukan secara random, pengumpulan data menggunakan instrumen penelitian, analisisdata bersifat kuantitatif/ statistik dengan tujuan untuk menguji hipotesis yang telah ditetapkan. Dalam penelitian ini, peneliti membahas pengaruh kecerdasan matematis logis terhadap kemampuan penalaran yang data-datanya dihitung secara kuantitatif. Sampel penelitian seluruh mahasiswa farmasi semester 1 yang terdiri dari 42 mahasiswa. Metode pengumpulan data yang digunakan adalah tes, wawancara, observasi, dan dokumentasi. Teknik analisis data yang digunakanadalah analisis regresi linier sederhana.

\section{HASIL PENELITIAN}

Berdasarkan uji tahap awal, peneliti menggunakan nilai ujian tengah semester mata kuliah statistika jurusan farmasi untuk dijadikan sebagai dasar awalmelakukan penelitian. Berdasarkan analisis tahap awal, hasil perhitungan diperoleh berdistribusi normal. Berdasarkan observasi hampir semua mahasiswa memiliki sifat pasif dan tidak aktif bertanya atau melakukan sesuatu yang mencolok saat pembelajaran berlangsung. Setelah dilakukan observasi, pertemuan selanjutnya diberikan tes untuk mengukur kecerdasan matematislogis dan kemampuan penalaran. Dari hasil analisis uji coba diperoleh 6 soal uraian untuk mengukur untuk mengukur kemampuan representasi matematis. Instrumen tersebut diujicobakan pada mahasiswa farmasi semester 3. Mahasiswa semester tiga merupakan kelas yang telah mendapat materi statistika pada saat semester 1. Tes kecerdasan matematis logis dilaksanakan pada tanggal 2 Desember 2017, setelah tes selesai dilakukan wawancara untuk mengetahui langkah-langkah dalam mengerjakan tes. Hasil tesyang telah diklarifikasi dengan wawancara menunjukkan bahwa tingkat kecerdasan matematis logis mahasiswa semester 1 farmasi Universitas Peradaban sebagian besar berada pada kategori sedang dengan persentase sebesar66,67\% atau sebanyak 28 mahasiswa, begitu pula dengan kemampuan penalaran mahasiswa yang berada pada kategori sedang dengan persentase sebesar73,81\% atau sebanyak 31mahasiswa. Sehingga dapat disimpulkan bahwa tingkat kecerdasan matematis logis mahasiswa semester 1 jurusan farmasi Universitas Peradaban berada pada kategori sedang. Perolehan skor untuk indikator-indikator tes kecerdasan matematis logis didapatkan skor tertinggi dengan rata- rata $84,22 \%$ pada indikator kemampuan berhitung dan skor terendah denganrata- rata $64,33 \%$ pada indikator berpikir logis. Perolehan tersebut menunjukkan bahwa sebagian besar mahasiswa semester 1 jurusan Farmasi memiliki kemampuan dalam menyelesaikan soal-soal terkait perhitungan. Akan tetapi, masih belum begitu mampu dalam menjawab soal-soal yang melibatkan pemikiran logis. Data-data yang telah diperoleh diuji menggunakan ujinormalitas, uji linieritas dan uji keberartian sebagai syarat agardapat dilakukan analisis regresi sederhana. Dari analisis normalitas variabel kecerdasan matematis logis diperoleh nilai Lhitung $=0,122$ dan Ltabel $=$ 0,134 dengan taraf signifikansi $\square=5 \%$. Berdasarkan data tersebut, Lhitung < Ltabel, maka data tersebut bersifat normal. Sehingga dua data tersebut dapat dilanjutkan perhitungannya menggunakan statistik parametrik. Sebagai syarat agar dapat dilakukan analisis regresi liniersederhana maka dilakukan uji linieritas dan keberartian. Uji linieritas diperoleh sebesar $\mathrm{F}$ hitung0,89< $\mathrm{F}$ tabel 2,87 dengan taraf signifikansi 5\%. Dan untuk uji keberartian diperolehsebesar F hitung 6,92> Ftabel 4,07 dengan taraf signifikansi 5\%. Berdasarkan data tersebut, dapat disimpulkan bahwa regresi $\mathrm{Y}$ atasX linier dan koefisien arah regresi berarti. Dari hasil analisis regresi sederhana kecerdasan matematis logis bernilai nol, maka kemampuan penalaran matematis sebesar poin, jika kecerdasan matematislogis naik sebesar 1 poin maka kemampuan dasar naiksebesar 0,399338 poin. Sedangkan dalam korelasi X dan Y diperoleh perhitung sebesar $0,4431>r(0,05 ; 42)$ sebesar 0,297 Sedangkan koefisien determinasi yang diperoleh sebesar 19,67\%. Dari data tersebut dapat diketahui bahwa terdapat hubungan yang positif dansignifikan antara kecerdasan matematis logis dan kemampuan penalaran dasar. Oleh karena itu, dapat disimpulkan bahwa kecerdasan matematis logis berpengaruh 
sebesar $19,67 \%$ terhadap kemampuan penalaran dasar mahasiswa farmasi semester 1 Universitas Peradaban sedangkan sisanya $80,33 \%$ dipengaruhi oleh faktor lain. Adanya pengaruh kecerdasan matematis logis terhadap kemampuan penalaran sejalan dengan pendapat MayLwin, dkk, karena orang berkecerdasan matematis logis memiliki kemampuan lebih dalam menangani bilangan dan perhitungan, pola, pemikiran logis dan ilmiah. Meskipun berkaitan denganangka, kecerdasan logis-matematis tidak berpusat dalam perhitungan angka secara terus-menerus, melainkan juga mengenai pemecahan masalah matematis. Berdasarkan uraian di atas, dapat disimpulkan bahwa kecerdasan matematis logis berpengaruh terhadap kemampuan penalaran mahasiswa farmasi semester 1 mata kuliah statistika Universitas Peradaban. Mahasiswa yang memiliki kecerdasan matematis logis tinggi akan memiliki kemampuan penalaran dasar yang tinggi pula.

\section{KESIMPULAN}

Berdasarkan analisis dan pembahasan diperoleh simpulan bahwa kecerdasan logis matematis berpengaruh terhadap kemampuan penalaran dasar mahasiswa farmasi semester 1 Universitas Peradaban. Hal ini dibuktikan dari hasil analisis regresi linier sederhana diperoleh persamaan = 34,65009+0,399338X. Artinya, jika kecerdasan matematis logis bernilai nol, maka kemampuan penalaran matematis sebesar poin, jika kecerdasan matematis logis naik sebesar 1 poin maka kemampuan dasar naiksebesar 0,399338 poin. Sedangkan dalam korelasi $\mathrm{X}$ dan $\mathrm{Y}$ diperoleh $\mathrm{r}$ hitung sebesar 0,4431> r
$(0,05 ; 42)$ 0,297. Sedangkan koefisien determinasi yang diperoleh sebesar 19,67\%. Dari data tersebut dapat diketahui bahwa terdapat hubungan yang positif dan signifikan antara kecerdasan matematis logis dan kemampuan penalaran dasar. Oleh karena itu, dapat disimpulkan bahwa kecerdasan matematis logis berpengaruh sebesar $19,67 \%$ terhadap kemampuan penalaran dasar mahasiswa farmasi semester 1 Universitas Peradaban sedangkan sisanya 80,33\% dipengaruhi oleh faktor lain.

\section{SARAN}

Berdasarkan hasil penelitian tersebut, penulis memberikan beberapa saran yang dirangkum sebagai berikut. Bagi peneliti lain, diharapkan mampu melakukan penelitian lanjutan terkait faktor-faktor lain yang memengaruhi kecerdasan matematis logis sehingga akan dapat memaksimalkan langkah dalam mengembangkan penalaran dasar mahasiswa. Bagi mahasiswa, dengan pengaruh kecerdasan matematis logis terhadap kemampuan penalaran, mahasiswa seharusnya melakukan beberapa kebiasaan yang dapat meningkatkan kecerdasan matematis logis. Bagi dosen pengampu, dengan adanya pengaruh kecerdasan matematis logis terhadap kemampuan penalaran dasar, dosen pengampu diharapkan dapat meningkatkan kecerdasan matematis logis sehingga kemampuan penalaran yang merupakan kegiatan berpikir logis untuk mengumpulkan fakta, mengelola, menganalisis, menjelaskan, dan membuat kesimpulan dapat meningkat

\section{DAFTAR PUSTAKA}

Azmi, Ulul. 2013. Profil Kemampuan Penalaran Matematika Dalam Menyelesaikan Masalah Matematika Ditinjau Dari Kemampuan Matematika Pada Materi Persamaan Garis Lurus Kelas VIII SMP YPM 4

Bohar Sidoarjo. Skripsi. Tidak diterbitkan. Surabaya: Institut Agama Islam Negeri Sunan Ampel Surabaya.

Clements, M. 1980. Analysis Children's Errors on Written Mathematical Tasks. 